Sociology, Morals and Mystery 
By the same author

The Life of Fohn Maynard Keynes

Towards a Dynamic Economics Reforming the World's Money Foundations of Inductive Logic

International Economics

(Cambridge University Press) 


\section{Sociology, Morals and Mystery}

The Chichele Lectures

Delivered in Oxford

under the auspices of

All Souls College,

I 970

ROY HARROD

Macmillan Education 
(C) Roy Harrod 1971

Softcover reprint of the hardcover 1st edition 1971 978-0-333-12341-6

All rights reserved. No part of this publication may be reproduced or transmitted, in any form or by any means, without permission.

$$
\begin{array}{r}
\text { First published I97 I by } \\
\text { MACM I L LAN AN D CO LT D } \\
\text { London and Basingstoke } \\
\text { Associated companies in New York Toronto } \\
\text { Dublin Melbourne Fohannesburg and Madras } \\
\text { Library of Congress catalog } \\
\text { card no. 7 I-I } 43998 \\
\text { ISBN 978-1-349-01135-3 } \\
\text { ISBN 978-1-349-01133-9 (eBook) } \\
\text { DOI 10.1007/978-1-349-01133-9 }
\end{array}
$$




\section{Contents}

Introduction I

I Mystery I 3

2 Morals and Manners $\quad 40$

3 Contribution of Economics $\quad 64$

4 Is There a Social Science? 90 